\title{
Te Tarata and Te Otukapuarangi: Reverse engineering Hochstetter's Lake Rotomahana Survey to map the Pink and White Terrace locations
}

\author{
REX BUNN \& SASCHA NOLDEN
}

\begin{abstract}
The Pink and White Terraces were New Zealand's eighth wonder of the world, until the Tarawera eruption on 10 June 1886 engulfed them. Without pre-eruption survey data, scientific and government teams failed to relocate the terraces, which were assumed lost. Over 20112012 GNS Science announced the rediscovery of parts of both terraces in Lake Rotomahana: however, by 2016 they resiled these claims, concluding the majority of both terraces destroyed.

This paper maps their original locations based on reverse engineering unpublished 1859 survey data from Ferdinand von Hochstetter. Evidence suggests the locations may have survived the eruption, with the terraces buried in ash, crossing the shoreline on land not subject to local volcanic cratering. Excavation is conceivable. The Pink and White Terraces may again delight visitors in Rotorua via the Terraces Track, complementing the world-class New Zealand walking tracks.
\end{abstract}

\section{Epigraph}

"Reverse engineering is a form of dependent creation, but this does not taint it, for in truth, all innovators, as the saying goes, 'stand on the shoulders of giants' as well as on the shoulder of other incremental innovators. Progress in science and the useful arts is advanced by dissemination of know-how, whether by publication, patenting or reverse engineering."

\section{Background}

In 2014, Rex Bunn was leading the PAWTL [Pink and White Terraces Limited] Project, which endeavoured to drain Lake Rotomahana and recover the terraces, based on the 2011-2012 GNS Science research. Following on from this Bunn undertook a skindiving expedition at the lake in search of evidence of the locations, and began writing up the story of the project and subsequent investigations in book form.

After responding to research enquiries during 2015, Sascha Nolden became increasingly interested and convinced of the seriousness of the mission to relocate the terraces. Having rediscovered Ferdinand Hochstetter's field survey notebooks and New Zealand manuscript maps in 2010, Nolden decided to share these with Bunn for the benefit of the project.

The collaboration proved fruitful, for while Nolden intends to publish these diaries from the survey in Auckland Province as editions of annotated translations of Hochstetter's diaries, similar to those of Nelson Province, the Rotomahana survey data appeared as lists of figures which interrupted the narrative and most likely its significance would have been overlooked in the edition. ${ }^{2}$ Nolden was also able to draw on extensive research into Hochstetter's correspondence, including letters to the cartographer August Petermann of Gotha who produced the first published map resulting from Hochstetter's survey of Lake Rotomahana in $1862 .^{3}$

The pleasing outcome was that Bunn was able to reverse engineer the compass survey data in this paper to fix the Pink and White Terrace locations, while Nolden was able to transcribe and translate some of the contextual descriptive notes around the survey coordinates. 


\section{Hochstetter's Lost Survey}

The advent of Hochstetter's Lake Rotomahana survey comes in a year which sees the discovery of a Shakespeare First Folio and notebooks showing nearly twice the known numbers of New Zealand soldiers served at Gallipoli. Like these, there is no question over the authenticity and provenance of the 1859 field diary used to locate the Pink and White Terrace locations. The diary was rediscovered in the Hochstetter Collection Basel by Sascha Nolden when he took up its curation in 2010 and the Lake Rotomahana pages were provided to Rex Bunn in 2016.

The pages come from the third volume of the diary completed by Dr Ferdinand von Hochstetter on his travels in New Zealand and cover the dates 15 April to 24 May 1859. The field diary returned to Europe with Hochstetter in 1860. The unruled pages are completed in Hochstetter's hand, using a pen and ink with pencil additions and pen and watercolour sketches and maps. Despite being written in the field, there is little smudging or other visible deterioration. The ink is hardly faded and the text mostly legible. Each section is dated and every page numbered. In a letter he wrote to his parents and siblings, dated Auckland, 27 May 1859, he writes, "I celebrated my 30th birthday on Rotomahana (warm lake), in a small hut on a small rocky island in the lake. Along the shore boiling water issues forth from fissures in the rocks and runs down in splendid cascades over sinter terraces of 80 to 100 feet in height - one of the most remarkable places in the world."4

The diary is written in mid-nineteenth-century German, with place names in Te Reo (Māori) and English. Just as mid-nineteenth-century English differs from modern English usage, so Hochstetter's written German reflects the orthography and usage of the period. Moving carefully, it took eight weeks to harvest the data required to reverse engineer the Pink and White Terrace locations. The translation and deciphering proceeded slowly using Cassell's 1925 (ninth edition) German-English dictionary and online translators, with Nolden translating more difficult sections. The survey material comprised compass bearing data, sketches, notes and a scale field map of Lake Rotomahana prepared using the method of squares. Hochstetter prepared the manuscript map of Rotomahana after returning to Europe based on his field survey data, observations and sketches. This map was completed in January 1861 and finally sent to the cartographer August Petermann in Gotha with a letter dated 17 May 1861. ${ }^{5}$ The field map is included below in Figure 1 followed by the first English language edition of the published version as Figure 2. 


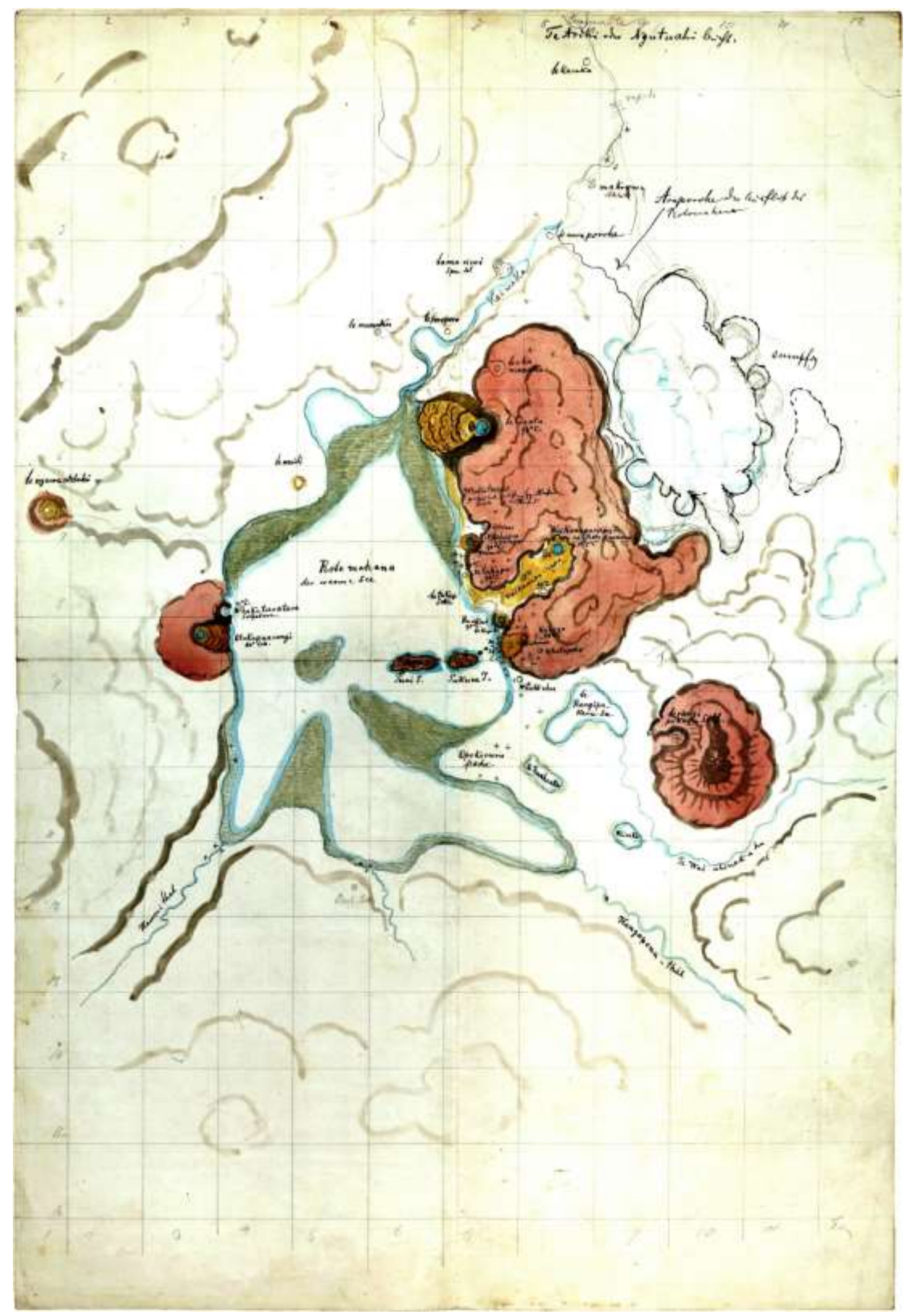

Fig. 1 Ferdinand Hochstetter, manuscript survey map of Lake Rotomahana, ca 1861. Reprinted from Sascha Nolden and Sandy B. Nolden, Hochstetter Collection Basel: Part 3-New Zealand Maps \& Sketches (Auckland: Mente Corde Manu, 2013). 




Fig. 2 Ferdinand Hochstetter, published map of Lake Rotomahana, 1865. Reprinted from Ferdinand Hochstetter and August Petermann, Geological and Topographical Atlas of New Zealand: Six Maps of the Provinces of Auckland and Nelson (Auckland: Delattre, 1864).

Hochstetter first mentioned the proposed publication of a map of Rotomahana in a letter to the cartographer August Petermann of Gotha, dated 1 November $1860 .{ }^{6}$ Here he offers to provide his survey data and sketches, including a draft manuscript map. He states that his sketch 
maps are based on observations from two points of observation and that his survey data are based on bearings taken with an azimuth compass. The data form part of a continuous network of bearings from the west to the east coast, based on the British Admiralty charts.

\section{Hochstetter's Diary Page 57}

On page 57 of the diary lie the most important bearings for those seeking the Pink and White Terraces. A translation of this page is shown below.

\section{$\underline{\text { Observations from a hill on the south side of Rotomahana }}$}

[Please refer to the above maps for the location of Hochstetter's Station 21. Beob. Stat. is an abbreviation for Beobachtungs Station or Observation Station]

1. Mr Spencer's 306 30'

2. Te Kumete ridge [with peaks sketch]

2.1 Left end peak $314^{\circ} 40^{\prime}$

2.2 Second left peak $322^{\circ} 40^{\prime}$

2.3 Third from left peak (Te Kumete) $326^{\circ} 0^{\prime}$ Highest Point

2.4 Fourth from left peak $334^{\circ} 20^{\prime}$

2.5 Mataneho Point on Tarawera Lake end [right end of Te Kumete ridge] $355^{\circ} 0^{\prime}$

3. Makatiti, highest point $359^{\circ} 20^{\prime}$

4. Te Ariki Point at Tarawera

North Point at the entrance of Te Ariki River $3^{\circ} 10^{\prime}$

5. Te Tarata, hot spring [i.e. at top of White Terrace] $8^{\circ} 10^{\prime}$

6. Ngahapu (hot spring) $5^{\circ} 20^{\prime}$

7. Te Tekapo (hot spring) $7^{\circ} 30^{\prime}$

8. Te Ruakiwi (hot spring) $11^{\circ} 10^{\prime}$

9. Ngawhana $17^{\circ} 0$ '

10. Otukapuarangi $322^{\circ} 20^{\prime}$

11. Te Whakataratara (Sulphur Pool) $336^{\circ} 0^{\prime}$

12. Te Mamaku (hot spring) $349^{\circ} 20^{\prime}$

13. Solfatara at Te Rangipakaru (foot of hill on West side of the hill) $43^{\circ} 10^{\prime}$

14. Whakaehu (hot spring) $17^{\circ} 50^{\prime}$

15. Te Puai Island, centre $7^{\circ} 0^{\prime}$

16. Te Pukura Island, centre $14^{\circ} 20^{\prime}$

17. Kaiwaka [channel] (Direction of the greatest length of the lake towards the Kaiwaka outlet) $357^{\circ} 0^{\prime}$

[NB: This North-South long axis of the lake is used as the baseline for photogrammetry i.e. the line joining the Haumi Stream exit to the lake and the Kaiwaka Channel entry to the North.]

18. Waiahinekahu $65^{\circ} 40^{\prime}$, a stream flowing East-West around the southern base of Te Rangipakaru hill. [Direction of the Te Waiahinekahu Valley]

19. Mount Tarawera, highest point, $43^{\circ} 30^{\prime}$

19.1 North-Western corner of the upper mountain plateau $46^{\circ} 10^{\prime}$

19.2 South-Eastern corner of the upper mountain plateau $33^{\circ} 0^{\prime}$

[NB: Transposition errors were detected in items 19 and 19.1, and corrected without altering the bearings. Item 19.2 contained a typographical error which was corrected. Item 15 contained an author's correction. Each error was resolved and validated.] 


\section{Survey Method}

The complex survey and cartographic challenge was not simply to compile Hochstetter's survey data into a survey of the old Lake Rotomahana. It was instead to reverse engineer his bearing data so we could plot where he stood to take those bearings from Station 21 and from Te Puai Island. Once we plotted those points, we established the survey baseline along which we could load his method-of-squares scaled map. This baseline gave orientation and scale for his field map. This seems simple looking back on it now, but it was not at all obvious.

Given the task of compiling a 157-year-old compass survey, the first requirement is to translate the magnetic bearings into today's terms. While the earth's geographic North Pole remains fixed, the second magnetic pole moves. The gap between the two poles is termed declination. Fortunately NOAA (National Oceanic and Atmospheric Administration), provide long-run declination adjustments, even for the Lake Rotomahana latitude and longitude. These crucial data allowed the 1859 Hochstetter bearings to be expressed in 2016 terms. In 1859 there were two north poles but in the digital age the use of the geographic or true north pole is passing and grid north, based on the UTM (Universal Transverse Mercator) map projection supersedes it. The difference between true north and grid north is termed convergence and for ordinary New Zealand mapping applications it can be immaterial. However, in the interests of accuracy the Hochstetter survey bearings were corrected for both declination and convergence before the necessary reciprocal bearings were computed.

Now each diary line, feature and bearing was deciphered, translated and located on today's topographic mapping. Given landform changes between 1859 and 2016 especially to skylines, this was not straightforward. The Makatiti peak (item 3 on diary page 57 above), illustrates this. There is a trig station on Makatiti today. It's at the eastern end of a small plateau. Whether for reasons of sightline, eruption landform change or tree cover development, Hochstetter did not choose today's trig station peak. Instead, he took the western peak as the highest point i.e. Hill 873. This was deduced weeks later when noting he showed only the western peak on another of his watercolour artworks completed during his visit. ${ }^{7}$ The screenbased methodology developed with his data used declination/convergence-corrected, reciprocal bearings to establish the latitude and longitude of Station 21 and the western end of Te Puai Island and is summarised below:

1) On a Topographic50 map screen, correct for convergence and 1859-2016 declination shift. Plot the reciprocal bearings in PowerPoint, on a $15: 10$ or $16: 10$ monitor screen, using a $360^{\circ}$ navigation protractor, adjustable set square and parallel rulers.

2) Extend the reciprocal bearings to monuments at the rear of the observation station e.g. Trig stations, cross-roads or electricity transmission pylons.

3) Measure along the rays i.e. from monument to locus, taking the mean of several bearings.

4) Transfer the rays to the www.nztopomaps.com site, rebuild the ray sets and the locus and record the coordinates.

5) Transfer the coordinates gained to the Google Maps ${ }^{\mathrm{TM}}$ map of Lake Rotomahana.

6) Construct the Station 21 to Te Puai island survey baseline.

7) Map the old lake features by standard map navigation technique i.e. taking True North bearings from each point, using the oriented Hochstetter watercolour scale field map for distances and bearings. 


\section{The Survey Takes Shape}

This initial survey processing took the ten Hochstetter bearings from the ten surviving posteruption landmarks visible from Station 21 and delivered a pleasing locus as shown in Figure 3 below.

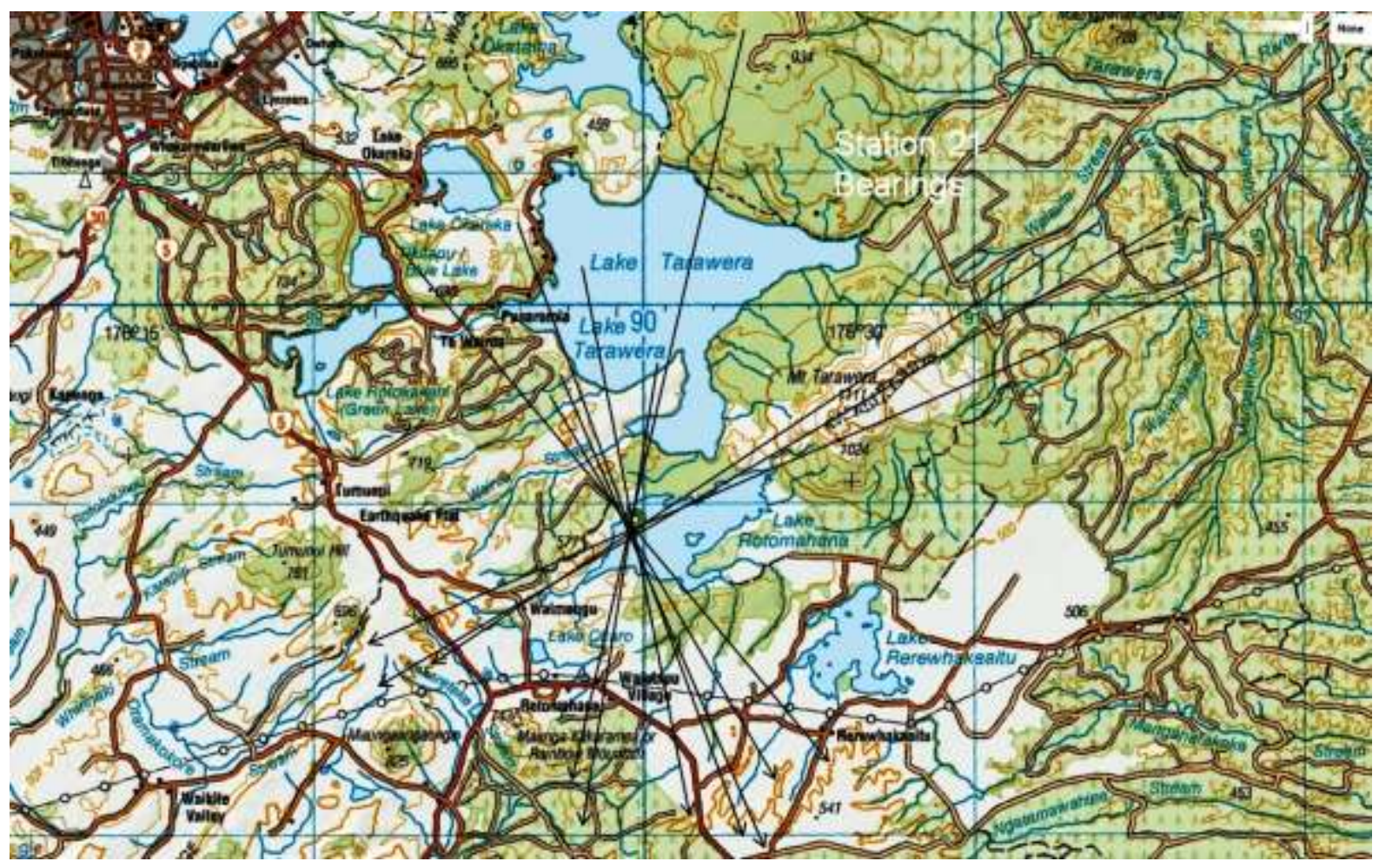

Fig. 3 Bearings Taken for Station 21, the Locus is shown in Black (CC BY-NC 3.0 NZ, NZTopomaps and A. R. Bunn).

One locus is insufficient for mapping with the nineteenth-century marine surveying technique Hochstetter used. This technique was based on that used by Commander Byron Drury (1815-1888) of the HMS Pandora survey ship in 1855. Hochstetter needed a second data point from which to construct the survey baseline. This location is found on page 53 of Hochstetter's diary where he refers to an island. There were only two significant islands on the old lake i.e. Te Puai Island and Te Pukura Island. Westerners stayed overnight on Te Puai Island, hence the coordinates were checked against the western end of Te Puai island and they agreed. The three check bearings intersected closely on the first mapping illustration reproduced below. Hochstetter had clearly chosen these landmarks because they resected at close to the ideal right angle, (which provides greater accuracy). The three red rays are the three (surviving landmark) back bearings which intersect on Te Puai Island, and the relative positions also marry on the field survey map. Joining the locus of the ten black rays in the figure above, with the locus of the three red rays in figure 4 below, provided the required compass survey baseline. The survey baseline could now be plotted on today's landscape, and the old Lake Rotomahana reconstructed around this baseline. 


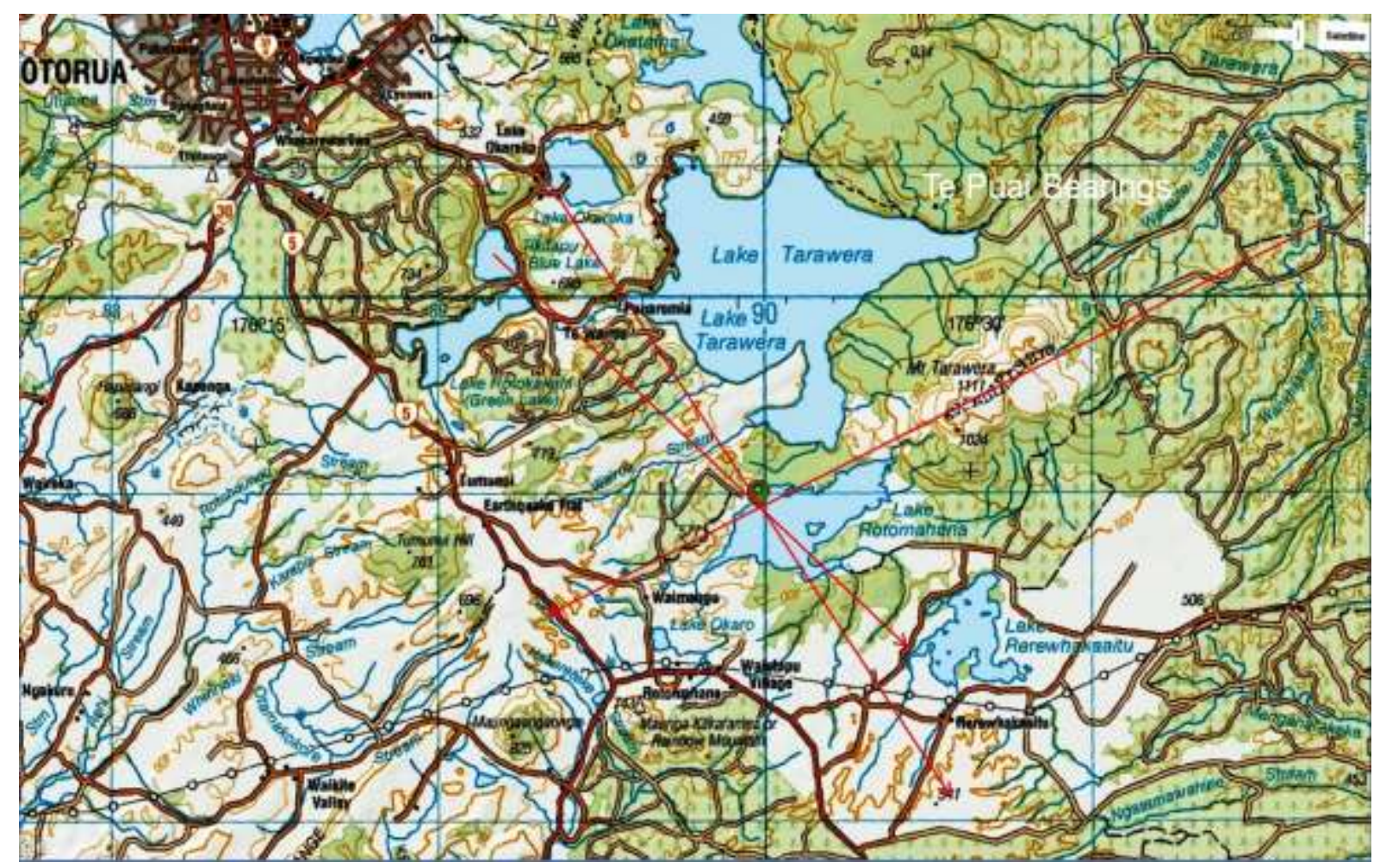

Fig. 4 Bearings taken for Te Puai Island, the locus is shown in red (CC BY-NC 3.0 NZ, NZTopomaps and A. R. Bunn).

For an overview of the topographical setting of the scene, Figure 5 reproduces a photograph by Daniel Louis Mundy published in 1875, showing Station 21, Te Puai Island and other salient features. Te Otukapuarangi is at three o'clock. Hape-O-Toroa Hill rises behind Oruakorako Hill.

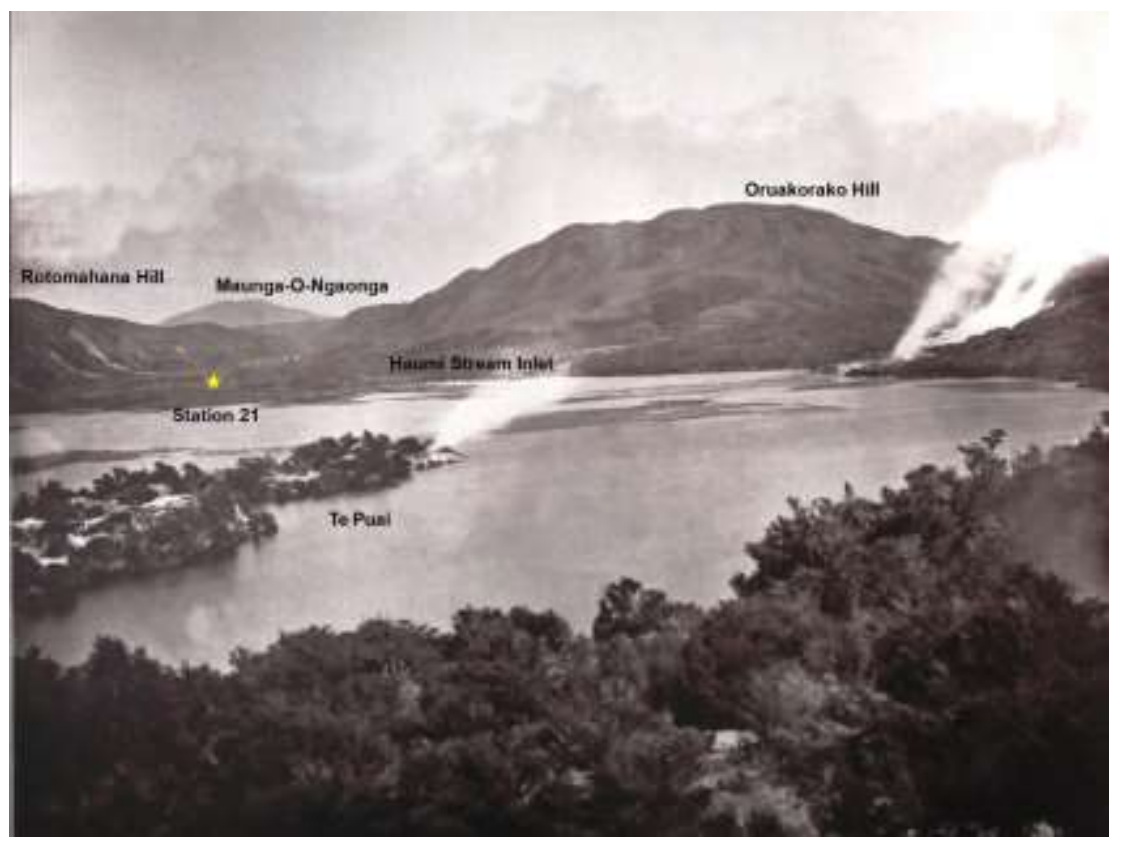

Fig. 5 The Southern Shores of the Lake, Te Puai and Te Pukura islands and the starred location of Station 21. Reprinted from Daniel L. Mundy, Rotomahana and the Boiling Springs of New Zealand (London: Sampson Low, Marston, Low, and Searle, 1875). 


\section{Locating the Pink and White Terraces}

With the survey baseline plotted, the material was transferred to Google Maps ${ }^{\mathrm{TM}}$ and using the standard map navigation technique, key features around the old Lake Rotomahana were plotted over the new Lake Rotomahana. The result is figure 6, below. Based on the Hochstetter survey, this is the first correctly scaled, oriented and positioned outline map of the original Lake Rotomahana in 130 years; and the first cartography to plot the Pink and White Terrace locations on today's topographic map.

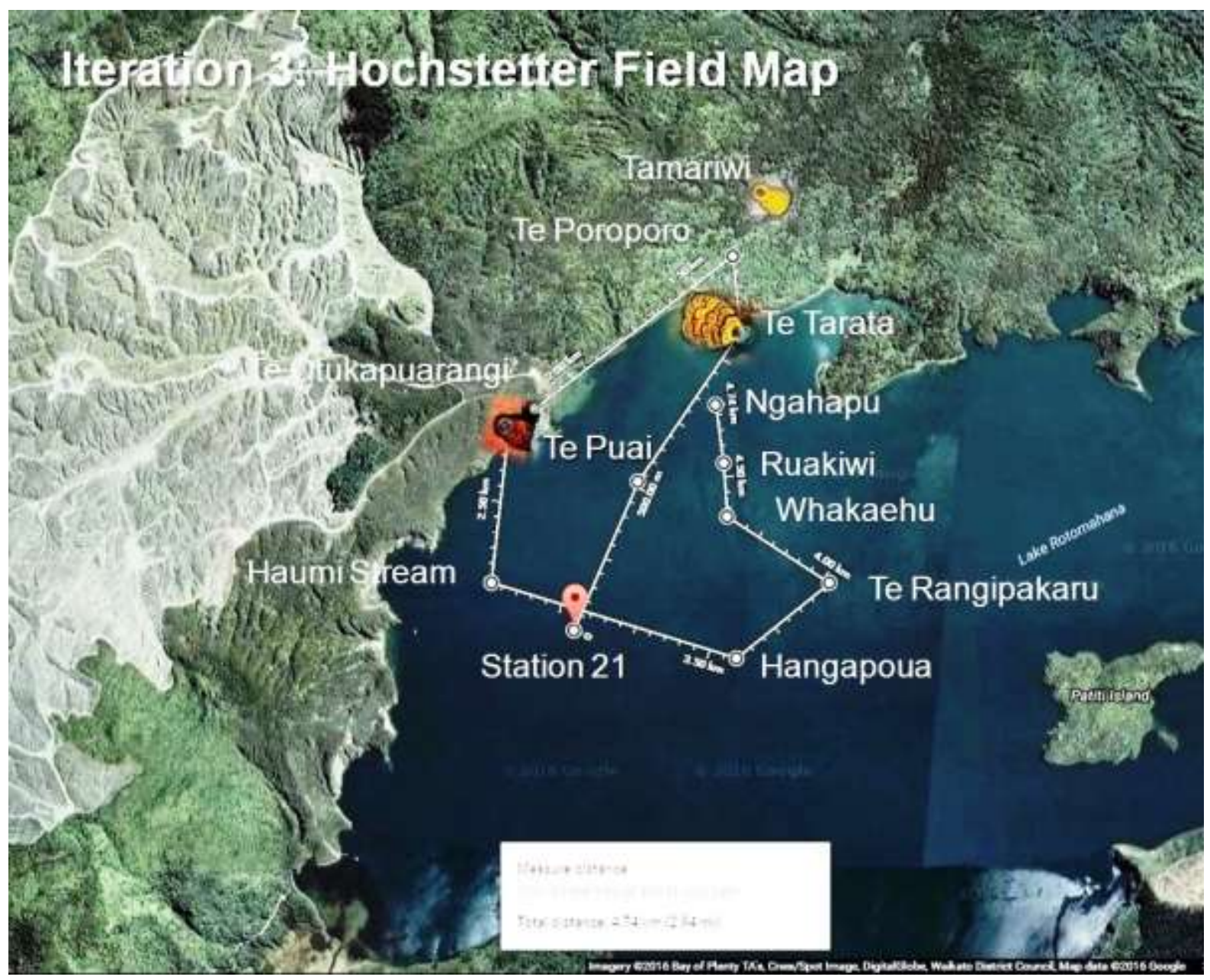

Fig. 6 Showing survey locations of surviving and lost geothermal features taken from Fig. 1 on Google Maps ${ }^{\mathrm{TM}}$.

In the above figure, both Pink and White Terrace locations lie partly on land and are not out in the deep lake, as generations of New Zealanders have been advised. Had the terraces lain completely over the lake (as do seven of the eastern features above), then like Te Puai Island, Great Ngahapu and the others, they would have been destroyed during the 1886 eruption. The illustrations of the Pink and White Terraces are by Hochstetter and are approximately to scale. The terraces each occupy the area and height of a city block. Note the Pink Terrace base location overlaps the present shoreline, with Te Otukapuarangi feeder spring inland (shown in blue). The blue feeder spring for Te Tarata lies close to the shore, with the great body of the White Terrace stretching along the shore and inland to the north and west along the northern lake shore. These surveyed terrace positions provide a coherent set of coordinates to replace 
the colonial conjecture. The history of Rotorua may need to be revised in light of the Hochstetter Survey findings.

Neither terrace location is near where the colonists and later generations imagined them to be. The White Terrace is westward of Te Tarata Point (the point at two o'clock in the above figure), and the Pink Terrace lies north of its reputed location i.e. in or near Te Otukapuarangi Bay (north of Haumi Stream above). Similarly, the assumed course of the old Kaiwaka Channel (north of Te Tarata Point), is now seen to be instead the Awaporohe Stream, with the Kaiwaka Channel entry lying away to the west and marked by Te Poroporo, the feature Hochstetter used as a surrogate for the Kaiwaka Channel entry.

\section{First Scuba Dive into Lake Rotomahana}

Only a month before undertaking the above cartographic work, and with the help of Harvey James of the Waimangu Volcanic Valley, Rex Bunn had organised the first scuba dive team to look for the Pink and White Terraces in Lake Rotomahana. This was in February 2016, just a fortnight before the Hochstetter source material was made available. Therefore we dived on three sites based upon (now superseded) reports as to likely terrace positioning. ${ }^{8}$ We were the first team reported to dive in Lake Rotomahana, save for GNS who used remotely-operated, submersible vehicles versus skin divers. Given the mercury and arsenic contamination in the lake from volcanic sources, it is not a healthy place to skin dive. Probably, this contamination was more pronounced in the old Lake Rotomahana.

Following the GNS 2011-2012 reports, we dived first on where Rex Bunn estimated the White Terrace to lie, south of Te Tarata Point. Here is an extract from the dive report that day: We entered the water above $38.259187,176.436075$ and searched to the south west, down the spur as planned, until we found a wide, flowing, layered shelf which initially looked a bit like a terrace, save it was black and abrasive to the touch. This formation was a wide shelf or series of what I can best describe as shelves stretching away into the murk. It appeared to have two or more layers and was one to two metres high and possibly more. It was however neither pink nor white ... but rather uniformly black. The word which sprang to mind on seeing it was ... flowing. ${ }^{9}$

Later, Cornel de Ronde of GNS Science kindly checked our coordinates, advising our find was not near his estimated White Terrace fragment but that there were hard sonar reflectors near the coordinates given and we may have found e.g. shoreline sinter formations which lay south of Te Tarata. ${ }^{10}$ At the time, this was encouraging.

Our second and third dives were on the estimated Pink Terrace locations around Te Otukapuarangi Bay (in figure 6 above, the large bay between Haumi Stream and Te Otukapuarangi). The dive locations were where we hoped to find the feeder spring for the Pink Terrace. On the northern aspect of Te Otukapuarangi Bay we did find a large, deep vent which was, from our dive report, " .. 5-10m wide, roughly ovoid on the surface and the basin or upper chamber (in lay terms) is $\sim 3-5 \mathrm{~m}$ deep, with a central fissure going down who knows how far. There was a little gas escaping the vent, as everywhere around there. The vent was located from memory, along a section of rocky shelf, which dropped off into the blue. Knowing of the magma chamber somewhere under there ... I'm not ashamed to say I found it a bit spooky."11 Based upon elapsed time from the GoPr0 ${ }^{\mathrm{TM}}$ video and the estimated kick-cycles from our known entry point, the deep vent was estimated to lie at coordinates $\sim 38.264115 \mathrm{~S}$, 176.420636E. From their bathymetry, GNS confirmed there was a vent at this location but it was not, as first imagined, the main volcanic vent which excavated Te Otukapuarangi Bay in 1886.

Our third dive was off the southern entry to Te Otukapuarangi Bay, at the location reported by Fitzgerald for the Pink Terrace. Here we recovered confirmed travertine-like, silica 
sinter on the lake floor but this was not evidence per se of a terrace. Silica sinter deposited from many hot springs around the shores of the old lake and this was merely one such piece. Later, Rex Bunn quipped to Cornel de Ronde "You may laugh but to me the burden of proof for any claim of terrace discovery ... is for the claimant to produce a piece of sinter containing laminated 19thC graffiti. I doubt anyone will meet that claim, any more than the Clay Foundation challenges!" 12 Cornel de Ronde replied he'd had the same thought some months earlier. The February dives provided a lot of research material but failed to produce evidence of either the Pink or the White terrace.

\section{Analysing the Hochstetter Survey}

In figure 6 above, the Pink Terrace location mapped by Hochstetter is lying largely on land and distally under water, with its northern section underground and the southern section beneath the lake floor. The Otukapuarangi spring location is a hundred metres inland, west of an unnamed point. It is buried shallowly, under ground rising to the west. The Pink Terrace lateral skirts cross the shore of the unnamed bay, approximately parallel at that point and about fiftyeight metres apart. The terrace south base nominally lies beneath the lake floor and this is about thirty-seven metres below the usual waterline of 340MASL (metres above sea level). In February 2016 the lake was low at 338MASL so the terrace lies about thirty-five metres below the water level. Having dived just south of that stretch of the lake, the water over the terrace base is five to ten metres deep. This places the Pink terrace base twenty-five to thirty-three metres beneath today's lake floor.

To the best of our knowledge, this Lake Rotomahana bay (like most others, given the catastrophic circumstances of the lake formation) has no name and as it may need to become familiar to visitors, it ought to be named. For purposes of this report, once the Warbrick family and hapu complete their evaluation, and subject to regulatory authority approval, we suggest this bay which lies north of Te Otukapuarangi Bay, become known as "Warbrick's Bay" for the Te Arawa guide, authority on Lake Rotomahana and later Chief Guide at Waimangu. Alfred Warbrick never gave up hope the Pink and White Terraces somehow survived the eruption, and we are sure he would be pleased to see the recent achievements of GNS Science and now this research helping realise his dream. ${ }^{13}$ Warbrick's Bay extends from coordinates $38.261000,176.422852$ to $\sim-38.259976,176.424928$.

From the February dive on the terrace sites, only one from the hundreds of images includes the location of the Pink Terrace. In the photo below, Te Otukapuarangi Bay is the first bay on the left side of the image. To the right, in the middle distance is the bay suggested to be named Warbrick's Bay. One may gain an idea of the depth of volcanic ash burying the terraces, from this photo, up to forty-five metres or more in places. The land falls around the coast from Warbrick's Bay to the north, illustrating why the White Terrace spring location is nearer the surface than the Pink spring. 


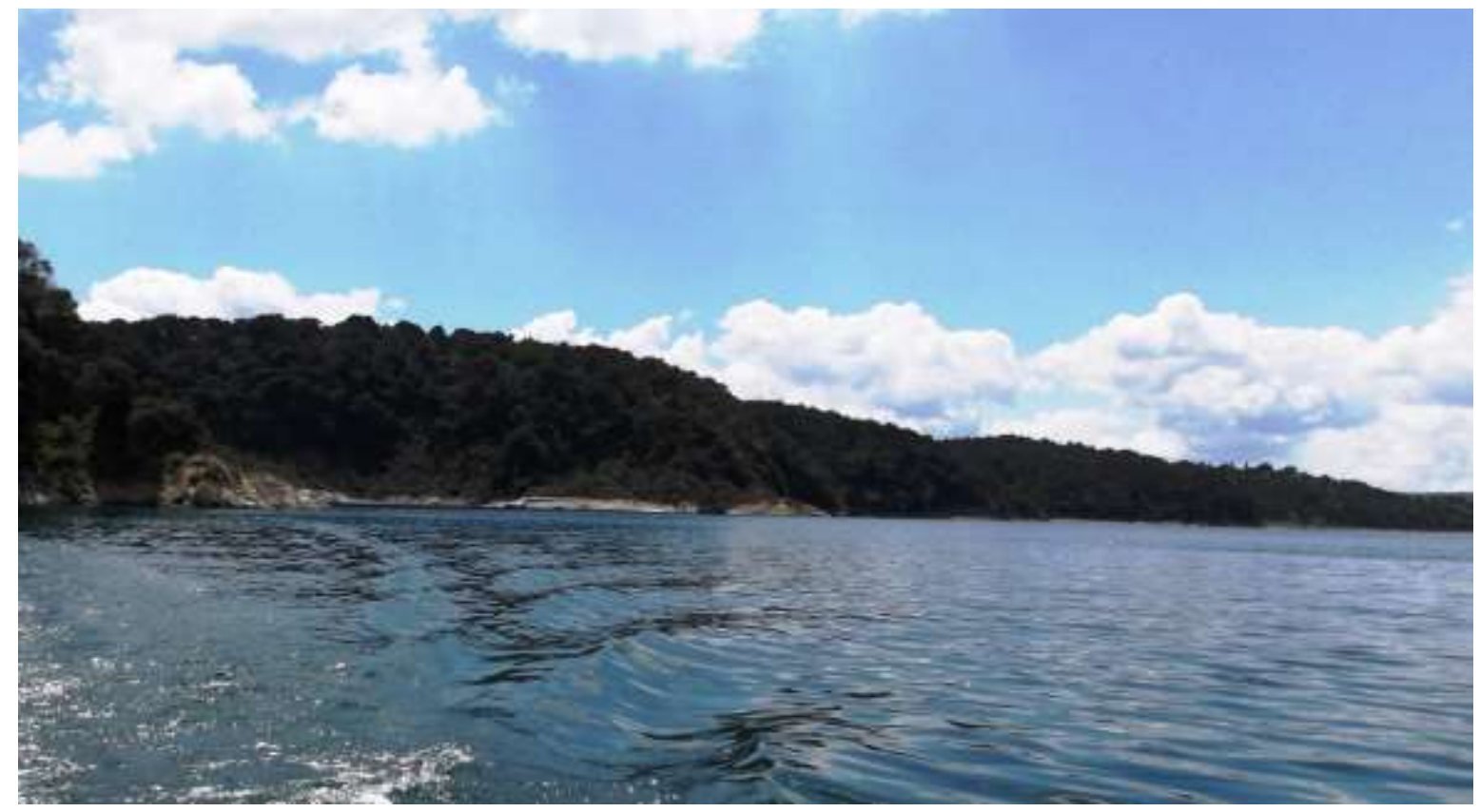

Fig. 7 Te Otukapuarangi Bay on the left and Warbrick's Bay with the Pink Terrace location, further to the right. Photograph by A. R. Bunn.

Below is the only shot from the February dive which includes the White Terrace site. The White Terrace spring location lies buried, out from the shore towards the middle of this photo.

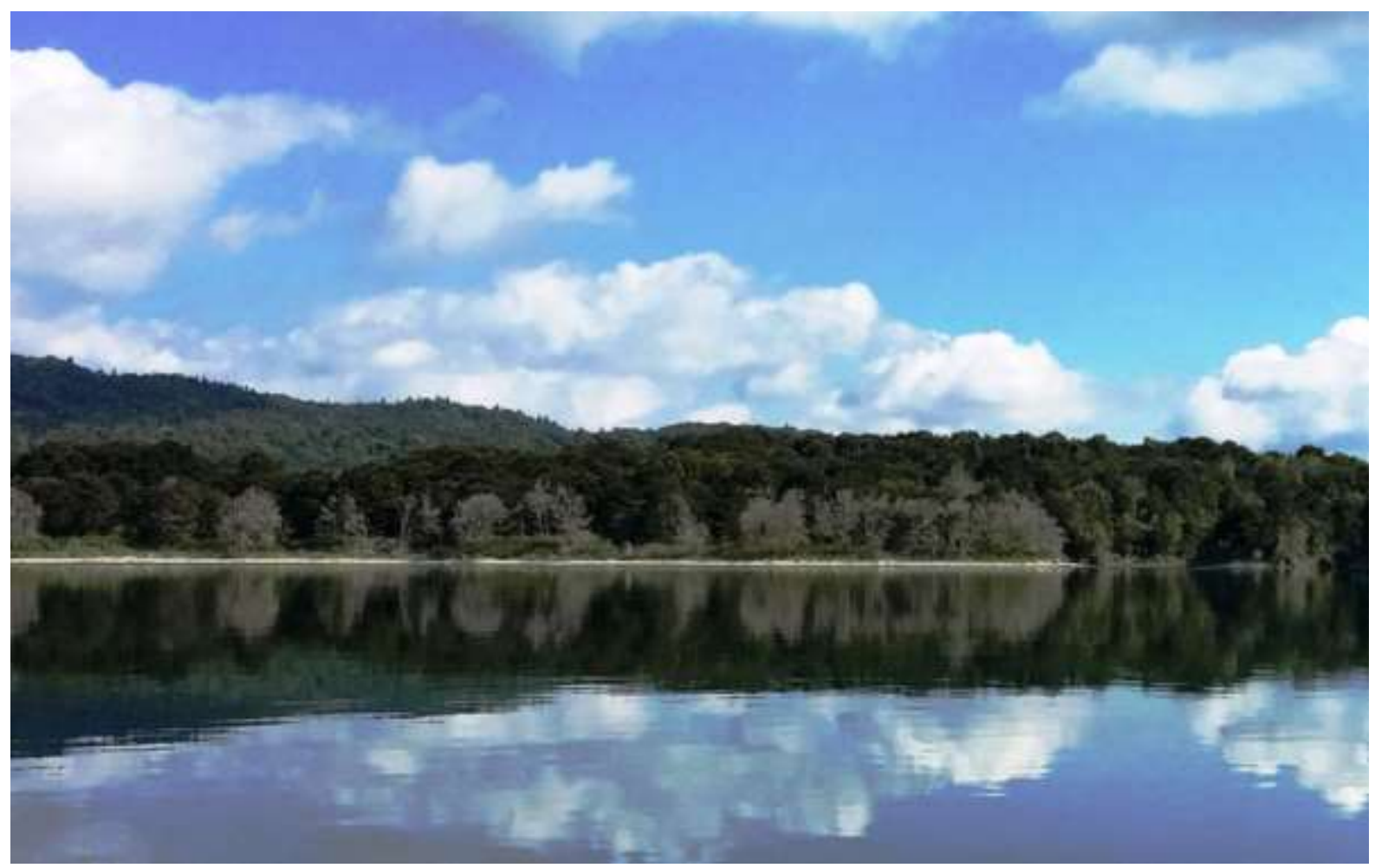

Fig. 8 The White Terrace location lies out from this lake shore. Photograph by Ingrid Fisher. 


\section{Why Now?}

One question immediately arises from this paper: Why has it taken until 2016 for Hochstetter's 1859 survey of Lake Rotomahana and the Terraces to be published? To address this we must consider the Pink and White Terraces from the time of this first survey and then during the period 1886 to 1936. In 1859, a party of twenty-one colonists and Māori had travelled in the North Island with Hochstetter, twenty-seven years prior to the Tarawera eruption. All the members were aware he was surveying the country with a view to publishing the first geological maps of the interior, following the HMS Pandora survey of the coastline. Some of the party, especially Augustus Koch and Julius Haast assisted with the surveying, while Major Drummond Hay acted as the interpreter, and Akutina Rangiheuea was the local guide. Most would have read Hochstetter's later books and/or seen the New Zealand maps he created, especially those of Lake Rotomahana. Hochstetter retained links with New Zealand until his death in 1884 , as evidenced by the published correspondence between Hochstetter and Haast. ${ }^{14}$ The $1886 \mathrm{Mt}$ Tarawera eruption and the Terraces' status stopped the nation. The first government expedition to report on the colony's greatest asset was rightly criticised, and a second was organised to address public scepticism in European and Māori communities. ${ }^{15}$ The second report findings were also questioned and now in 2016, finally superseded by the Hochstetter Survey. ${ }^{16}$ A third inter-university report on the eruption and terraces was delayed two years and it also wrongly concluded the Pink and White Terraces were destroyed. ${ }^{17}$

Te Arawa tribal representatives were the first on the eruption scene. They reported the terraces were sighted and were disbelieved. Many of Te Arawa remained sceptical about the government inquiries and this report vindicates their judgment. Alfred Warbrick led a fiftyyear campaign to drain the lake and recover the terraces. The media debate over this only ceased with his death in 1940. As some of the colonists who assisted Hochstetter's 1859 Rotomahana survey were alive in 1886, it's open to question why none went on record over 1886-1887 to suggest that Hochstetter's survey be retrieved and compiled to demonstrate the terrace locations and answer the persisting question of their survival or demise. While Hochstetter died two years before the eruption, his survey records, if known to be extant, might have been sought and potentially repatriated to New Zealand during 1887. For example, Haast, who was in Europe at this time, could have arranged this. The fact the existence of these survey records remained unknown or forgotten, left the colonial government promoting the misconception that the Pink and White Terraces were destroyed. Illustrating that this colonial myopia persisted into the next century, is the 1927 DSIR (Department of Scientific and Industrial Research) report to Parliament wherein L. I. Grange, the geologist reporting for the Rotorua Subdivision reiterated the misconception: "No detailed geological survey has ever been made of any part of the volcanic region, and therefore I urged that such a survey was of prime importance, and should precede any or accompany systematic vulcanological observations." 18

\section{Hochstetter and GNS Science Reports on the Pink and White Terraces}

After the abortive government inquiries in the 1880s, university, local government staff and independent researchers in the twentieth century often visited Lake Rotomahana and a good deal of bathymetry and limnology was performed. However, no previous scientific lake research compared to that undertaken by the three expeditions to Lake Rotomahana over 2011, 2012 and 2014 organised by Dr. Cornel de Ronde of GNS Science. After their first visit with a submersible vehicle in 2011, Dr. de Ronde announced they and a consortium from WHOI (Woods Hole Oceanographic Institution), the University of Waikato and others had found part perhaps even the entire Pink Terrace and later the White Terrace deep in Lake Rotomahana. Their press releases caused intense excitement in the world media during 2011 and 2012. "The terraces were never destroyed," Dr. de Ronde said. "They never went anywhere. What 
happened to them is that they got completely and utterly covered in up to 10 meters of thick mud, which was all excavated out of the old lake. And then, when the waters rose, they and their muddy cloak disappeared from view entirely." 19 In 2016, as the GNS Science Lake Rotomahana research is published via a tranche of papers in a special edition of the JVGR (Journal of Volcanology and Geothermal Research), GNS appear to resile from their 20112012 terrace claims, now stating: "We believe that the majority of both sets of terraces were destroyed during the eruption. However, some tantalizing evidence exists for remnants from both sites to exist to this day." (de Ronde et al. 2016). These 2016 remnants' coordinates can be plotted from the illustrations in the GNS tranche and appear to differ to those coordinates from 2011 and 2012. The Pink Terrace position appears to have moved 300 metres south from its reported 2011-2012 position, as estimated in the figure below showing Hochstetter and GNS positions for Te Otukapuarangi.

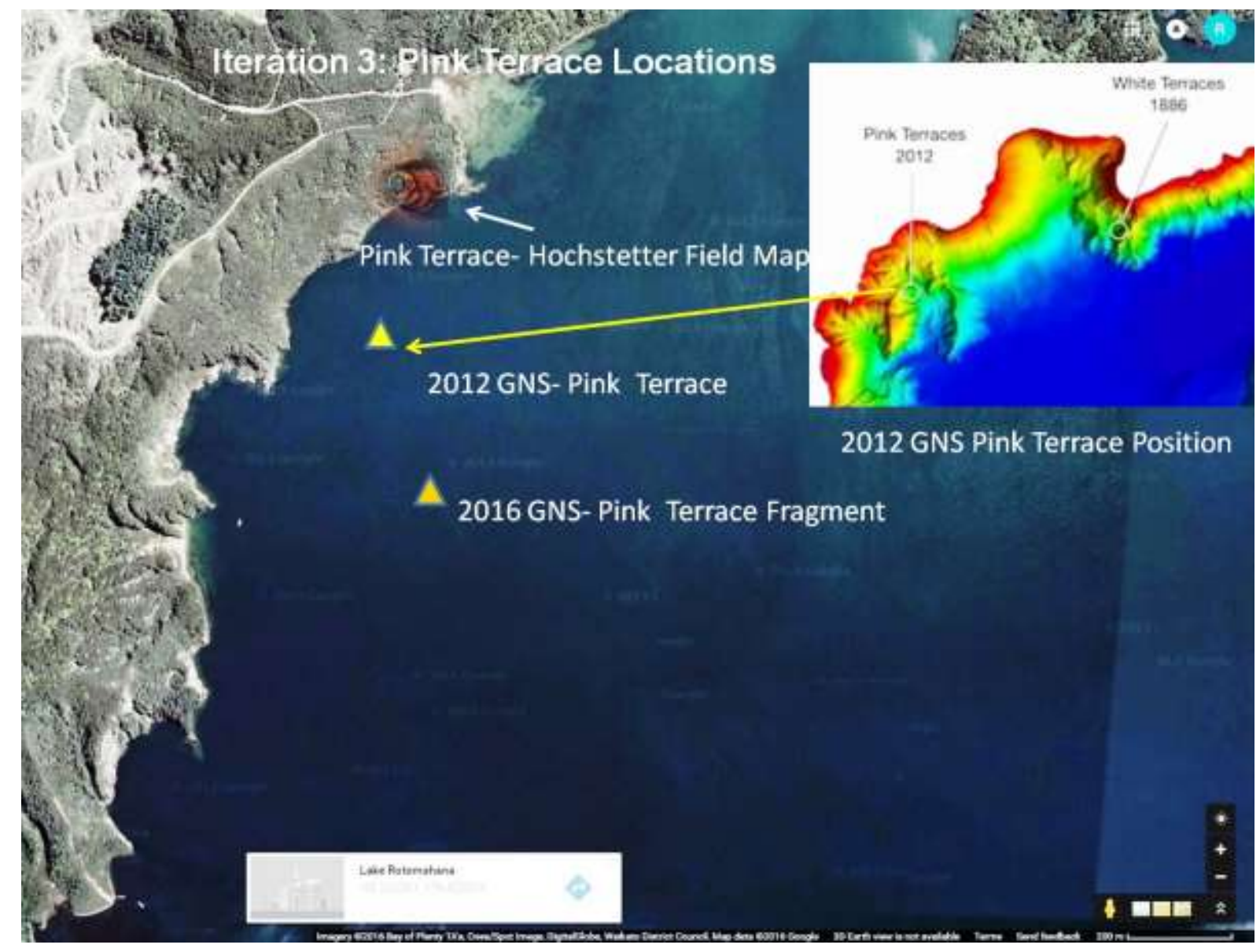

Fig. 9 Hochstetter, 2011-2012 GNS and revised 2016 GNS coordinates for the Pink Terrace and Basal Fragment. Image compiled from Google, GNS, Cornel de Ronde, and A. R. Bunn.

In mid-2016, when plotting figure 9 above, there was striking agreement between the Pink Terrace positioning, based on Hochstetter's survey and the 2011-2012 GNS sighting of Pink Terrace-like material south of that same bay i.e. "Warbrick's Bay." On Hochstetter's bearings, the base of the Pink Terrace jutted out above the bay where Cornel de Ronde reported finding his terrace fragment. The Hochstetter survey places the original base of the Pink Terrace at about thirty-five to thirty-seven metres below the new lake surface versus the GNS 
finding at about sixty metres below the surface, a gap of twenty-two to twenty-three metres. This gap could be explained by slumping of the crater wall or by the Pink Terrace base being undermined during the eruption, the terrace fracturing and the basal section sliding down the side of the Rotomahana volcano, until it lodged in the crater on a ledge sixty metres down; while the mother-section above was stabilised and buried by a growing weight of volcanic ash. Indeed, Cornel de Ronde coincidentally offers a similar possibility in one of his 2016 papers in press: "with considerable upheaval of the landscape post-eruption, it is entirely conceivable that slumping may have occurred locally, transporting competent structures like the terraces downslope." 20

The Hochstetter Survey appears to validate the GNS 2011-2012 Pink Terrace fragment claim. However, in the 2016 GNS papers the revised Pink Terrace site is not as consistent with the Hochstetter Survey, for given the latest bathymetry it is hard to see how a huge terrace fragment could reach the reported 2016 position. There is also one counter-argument to the coincidental "Warbrick's Bay" validation and this arises from the relative elevations. The 2012 GNS Pink terrace site lies 200 metres from land, in 60 metres of water. Hochstetter shows $\sim 20$ metres of terrace overlapped the new lake shoreline. Having dived around the northern entrance to Te Otukapuarangi Bay i.e. immediately south of the Pink Terrace location ... we can report the shoreline there has a shallow slope. At 20 metres out from the lake edge I estimate the water in Warbrick's Bay is 5-10 metres deep today i.e. the lake floor there lies at 328-333MASL. Given the Pink Terrace base and side buttresses were at water level i.e. $\sim 303$ MASL from the Kaiwaka Channel datum, this means they are 35 metres below today's lake level in early 2016 and the base lies 25-30 metres below today's lake floor. At this elevation, it is hard to see how the basal section of the Pink Terrace could have been exposed by the eruption stages, for if we take today's western shoreline as approximately corresponding to the 1886 crater rim, then the Pink Terrace was quickly buried during the eruption and could never have been undercut or fractured for a fragment to have slid 200 metres down as in the above scenario. On this reasoning, the Pink and part of the White Terraces remained on land before, during and after the 1886 eruption; and are not amenable to discovery by a submersible vehicle.

\section{Conclusions}

We conclude Hochstetter's bearings constituted a practical compass survey in 1859; one which has been reverse engineered into current mapping and surveying terms and validated by a Data Quality Report. ${ }^{21}$ Both terrace locations, with the exception of the south-basal section of Te Otukapuarangi (the Pink Terrace) and the southern aspect of Te Tarata (the White Terrace) were not in line with any known local eruption vents around the northern or western shores of the old and new lakes. Both terrace sites are tens of metres underground, with the exception of the fractured base of Te Otukapuarangi which, it appears, might have slid down the main Rotomahana crater wall and rested on a ledge for 125 years, before being fortuitously found by Cornel de Ronde's submersible. If correct, the GNS rediscovery claim raises the likelihood that the majority, upper masses of the Pink Terrace are lying in their original location, where we expect them to be from Hochstetter's survey i.e. above and west of the GNS remnant and about twenty-five metres underground. The White Terrace location is also underground and beneath the lake floor: both locations indicate the terraces were deeply buried by volcanic ash from the Mt Tarawera and Lake Rotomahana craters, the latter craters being recently mapped by the 2014 GNS Science consortium.

The coincidental timing of the GNS Science expeditions to Lake Rotomahana with the rediscovery and publication of the Hochstetter Survey of the old Lake Rotomahana seems a good example of the concept of multiple independent discovery. It is ironic GNS Science concluded the terraces were largely destroyed, just as we gained the first evidence the Pink and 
White Terrace locations survived the 1886 eruption, and we now have coordinates for both terrace locations. While the Pink and White Terrace locations may prove to lie below the watertable making excavation difficult, it is more practicable to excavate the lesser-known third terrace of old Lake Rotomahana i.e., Te Tuhi's Spring. Te Tuhi's Spring, also known as the Black Terrace Crater, lies at a higher elevation, was the only pre-eruption geothermal feature to survive in the post-eruption landscape, and may one day be excavated so visitors can look down into the underworld of old Lake Rotomahana and the Pink and White Terraces. Te Tuhi's Spring makes a logical start to the mooted "Terraces Track," connecting the existing Tarawera Trail to Mt Tarawera via Lake Rotomahana and passing over many of Hochstetter's survey landmarks and the famous pre-eruption geothermal features, including Te Otukapuarangi and Te Tarata. Such a grand traverse would match the famed Tongariro Crossing as a tourist attraction. By this path, the Pink and White Terraces may in some small way return, to delight visitors to Rotorua as they did in the nineteenth century.

\footnotetext{
${ }^{1}$ Pamela Samuelson and Suzanne Scotchmer, "The Law and Economics of Reverse Engineering," Yale Law Journal 111, no. 7 (May 2002): 1662.

${ }^{2}$ Mike Johnston and Sascha Nolden, Hochstetter's First Nelson Diary: 27 July-5 September 1859 (Takaka: Geoscience Society of New Zealand, 2014); Mike Johnston, Sascha Nolden, and Leonore Hoke, Hochstetter's Nelson Diary: 6 September-2 October 1859 and Dun Mountain Report (Wellington: Geoscience Society of New Zealand, 2012).

${ }^{3}$ Ferdinand Hochstetter, "Roto mahana oder der Warme See in der Provinz Auckland auf der Nordinsel von Neu-Seeland," Mittheilungen aus Justus Perthes Geographischer Anstalt 8, no. 7 (1862): 236-66, plate 10; Brian Marshall, "Justus Perthes \& August Petermann: Some $19^{\text {th }}$ Century New Zealand Maps Produced in Germany," Turnbull Library Record 31 (1998): 63-76.

${ }^{4}$ Ferdinand Hochstetter, letter to his family, Auckland, 27 May 1859, Hochstetter Collection Basel, Archive of the Department of Geology and Palaeontology, Natural History Museum, Vienna, Austria.

${ }^{5}$ Ferdinand Hochstetter, letter to August Petermann, Vienna, 17 May 1861, Briefsammlung Ferdinand Hochstetter, Mappe 60, Sammlung Perthes, Schriftleitung Petermanns Geographische Mitteilungen, Forschungsbibliotek Gotha, Gotha, Germany.

${ }^{6}$ Ferdinand Hochstetter, letter to August Petermann, Vienna, 1 November 1860, Briefsammlung Ferdinand Hochstetter, Mappe 60, Sammlung Perthes, Schriftleitung Petermanns Geographische Mitteilungen, Forschungsbibliotek Gotha, Gotha, Germany.

${ }^{7}$ Cat. no. 3.5.6 in Sascha Nolden and Sandy B. Nolden, Hochstetter Collection Basel: Part 3 - New Zealand Maps \& Sketches (Auckland: Mente Corde Manu, 2013).

${ }^{8}$ These locations were described in GNS Science, Lake Rotomahana Project 2011 (Project Report, 2011); Herbert F. Fitzgerald, The Pink and White Terraces Revisited (Rotorua: H. F. Fitzgerald, 2014); and Ronald F. Keam, Tarawera: The Volcanic Eruption of 10 June 1886 (Auckland: R. F. Keam, 1988).

${ }^{9}$ Alfred R. Bunn, Quest for the Pink and White Terraces, rushes, https://www.youtube.com/watch?v=L9YHJjPTrX8, uploaded 6 May, 2016.

${ }^{10}$ Cornel de Ronde, personal email correspondence with A. R. Bunn.

${ }^{11}$ Bunn, Quest for the Pink and White Terraces.

${ }^{12}$ Bunn, personal email correspondence with de Ronde.

${ }^{13}$ Alfred Warbrick, Adventures in Geyserland: Life in New Zealand's Thermal Regions, Including the Story of the Tarawera Eruption and the Destruction of the Famous Terraces of Rotomahana (Dunedin: Reed, 1934).

${ }^{14}$ Sascha Nolden, The Letters of Ferdinand von Hochstetter to Julius von Haast (Wellington:

Geoscience Society of New Zealand, 2013).

${ }^{15}$ Keam, Tarawera, 330-33.
} 
${ }^{16}$ Keam, Tarawera, 330-33.

${ }^{17}$ Keam, Tarawera, 330-33.

${ }^{18}$ Leslie I. Grange, DSIR Parliamentary Report (Clerk of the House of Representatives, 1927), 14. https://atojs.natlib.govt.nz/parliamentary/appendix-to-the-journals-of-the-house-ofrepresentatives/1927/I/3654.

${ }^{19}$ Cherie Winner, "In Search of the Pink and White Terraces; WHOI vehicles help find landmarks lost in 1886 eruption," Woods Hole Oceanographic Institution: Oceanus Magazine 49, no. 2 (May 2012). http://www.whoi.edu/oceanus/feature/in-search-of-the-pink-and-white-terraces.

${ }^{20}$ Cornel E. J. de Ronde, Daniel J. Fornari, V. L. Ferrini, Sharon L. Walker, B. W. Davy, C. LeBlanc, Fabio Caratori Tontini, Amy L. Kukulya, and R. H. Littlefield, "The Pink and White Terraces of Lake Rotomahana: What was their Fate after the 1886 Tarawera Eruption?" Journal of Volcanology and Geothermal Research 314 (February 2016): 126-41.

${ }^{21}$ This Report is available from Rex Bunn. 